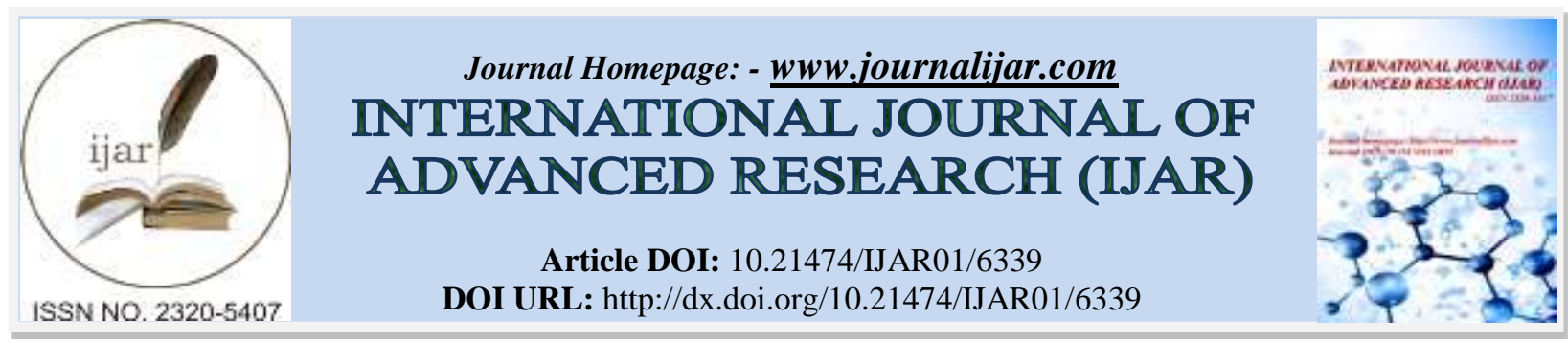

RESEARCH ARTICLE

\title{
STUDIES ON ECHERICIA COLI ISOLATED FROM MASTITIC CATTLE AND COMPARATIVE REVEALANCE TO HUMAN.
}

Ashraf. A. AbdEL-Tawab ${ }^{1}$, Fatma. I. El-Hofy ${ }^{1}$, Khalid. I. El-ekhnawey ${ }^{2}$ and ${ }^{*}$ Fawzia. A. El-Shenawey ${ }^{3}$.

1. Bacteriology, Immunology and Mycology Department Faculty of Veterinary Medicine, Benha University, Egypt.

2. Animal Health Research Institute. Dokki, Egypt.

3. Animal Health Research Institute, tanta branch, Egypt.

\section{Manuscript Info}

Manuscript History

Received: 18 November 2017

Final Accepted: 20 December 2017

Published: January 2018

Key words:-

E. coli Mastitis Contact human Shiga toxin Gene sequencing.

\section{Abstract}

A total of 50 clinical mastitic milk samples, 42 sub clinical mastitic milk samples ( positive with California Mastitis Test) and 40 hand swabs from contact human were collected from different dairy farms at Gharbia governorate and investigated bacteriologically to isolate Ecshericia coli. Among clinical mastitic samples a total of 5 isolates $E$. coli $(10 \%)$, from sub clinical mastitic samples 3 isolates $(7.4 \%)$ were detected, while 3 isolates $(7.5 \%)$ were recovered from contact human hand swabs. E. coli isolates were serotyped under 6 different $\mathrm{O}$ serotypes $\left(\mathrm{O}_{27}\right.$ and $\left.\mathrm{O}_{55}\right)$ isolated from contact human while $\left(\mathrm{O}_{6}, \mathrm{O}_{86}\right.$, $\mathrm{O}_{114}, \mathrm{O}_{27}$ and $\mathrm{O}_{157}$ ) isolated from mastitic milk. Antibiotic sensitivity revealed that all isolates were fully susceptible to enerofloxacin, ciprofloxacin, while all isolates were fully resistant to penicillin. E. coli serogrouped isolates were subjected to PCR for detection of Stx 1 and Stx 2 genes. 3 out of 7 serogrouped isolates $(42.85 \%)$ were carried Stx2 gene (O55 and O27 from contact human and 086 from mastitic milk) while Stx 1 gene was not detected. phylogenetic analysis for the sequence data of the Sxt2 gene of E. coli serogroupes revealed that $S x t 2$ gene isolated from mastitic milk of cattle is closely identical ( $100 \%$ identity) to $S x t 2$ gene isolated from contact human. In Conclusion, isolation of STEC from cattle might have potential pathogenicity for human. So that contact human should use sound hygienic measures during milking and management of these animals to avoid zoonotic infection.

Copy Right, IJAR, 2018,. All rights reserved.

\section{Introduction:-}

Mastitis is known by an inflammation of the mammary gland and is the leading one, that can contribute to reduce milk production and it is one of the common problems of dairy (Fekadu, 1995; Mekonnen et al., 2005.) . It is obviously an important factor that limits dairy production. Mastitis resulted in financial loss due to reduction of milk yield, discarded milk following antibiotic therapy, veterinary expense and culling of mastitic cows (Radostitis et al., 2007). 
It is primarily caused by an invasion of mammary tissues by pathogenic microorganisms through the teat canal resulting in physical, chemical, pathological changes in glandular tissues and milk (Quinn et al., 2002; Radostitis, 2007).

Ecshericia coli is one of the most common causes of bovine clinical mastitis. The incidence of E. coli mastitis has increased in some countries in recent years (Green et al., 2005). It is a major problem in lactating dairy cows (Kobori et al., 2004).

Environmental contamination with faces is the main source of mastitis-causing E. coli bacteria (Nemeth et al.,1994). The controls of mastitis in dairy herds are accomplished in part with the aid of Antibiotics (NMC, 1999). Public hazards associated with the consumption of antibiotic contaminated milk results in allergic responses, changes in intestinal flora and development of antibiotic resistant pathogenic bacteria (Thirapatsakun, 1999).

Virulence factors of the bacterial strain can give it a chance for colonization, multiplication and survival in udder in the face of host defense mechanism (Kaipainen et al., 2002). The shiga toxin producing E. coli (STEC) strains can cause mastitis in bovine and reduce milk quality for human consumption (Momtaze et al., 2012). Many studies concluded that the STEC strains are the most prevalent resources for milk poisoning ( Solomakos et al ., 2009). About $82 \%$ of the STEC strains of animal origin belong to similar serotypes detected in humans, and $51 \%$ of these belong to serotypes related to human infection with HUS (Blanco et al., 2004a). Also, other infection routes may occur through direct contact with carrier animals and indirect contact with contaminated environments (Keen et al., 2006).

The objective of this study was to apply bacteriological and molecular studies on Ecshericia coli isolated from mastitic cattle and comparative revealance to human contact.

\section{Material and methods:-}

\section{Sampling:}

A total noumper of 50 mastitic milk samples, 42 positive California mastitis milk samples and 40 hand swabs from contact human were collected from different dairy farms from Gharbia governorates.

\section{Milk samples:-}

Mastitis milk samples were collected aseptically into screw capped bottles and kept at 4oC until microbiological examination. Twenty five $\mathrm{ml}$ from each sample were homogenized with $225 \mathrm{ml}$ of buffered peptone water (BPW) for pre-enrichment and incubated at 37oC for $24 \mathrm{~h}$ (Addis et al., 2011a).

\section{Contact human hand swabs:-}

Moistened sterile swabs were rolled over the palm of hands, finger tips, nails and area between fingers. Each swab was inserted in tubes containing BPW for pre-enrichment.

\section{Bacterial isolation by cultivation:-}

A loopful from the pre-enriched culture homogenate in BPW was streaked onto the surface of MacConkey`s agar, Eosin Methylene blue (EMB) agar media. The inoculated plates were incubated at $37^{\circ} \mathrm{C}$ for 24 to 48 hours then examined for bacteriological growth. Greenish metallic shinny colonies on the plates were purified on nutrient agar slants and incubated at $37^{\circ} \mathrm{C}$ for $18-24$ hours for further identification. (Ojo et al., 2010).

\section{Serological identification of $E$. coli isolates:-}

The isolated strains of $E$. coli were identified serologically by using polyvalent and monovalent antisera for diagnosis of pathogenic serotypes according to Varnam and Evans, (1991).

\section{Antimicrobial susceptibility testing:-}

according to (Quinn et al., 1994) and (Winn et al. 2006) E. coli isolates were examined in vitro for their susceptibility to the following antimicrobial discs: enerofloxacin (Enr 10 ), ciprofloxacin (Cip 5), penicillin (P 10), amoxicillin/Clavulanic acid(Amc 10), oxytetracyclin (OT 30), gentamicin (Gen 30) and sulpha trimethoprim (Sxt 25). 


\section{Extraction of bacterial DNA:}

DNA was purified according to QIAamp DNA mini kit instructions.

duplex PCR for identification of Shiga toxin genes (Stx 1\& Stx 2):

Purified DNA of E. coli isolates was subjected to a duplex PCR for the identification of Shiga toxin genes ( Stx $1 \&$

Stx2 ) using specific oligonucleotide primers according to (Dipineto et al., 2006) as shown in the table (1) and agarose gel electrophoreses according to (Sambrook et al., 1989) with agarose gel (1.5 g). The PCR condition

for amplification was conducted according to (Dipineto et al., 2006). Briefly, initial denaturation was performed at $94 \mathrm{oC}$ for $5 \mathrm{~min}$ followed by Secondary denaturation at $94 \mathrm{oC}$ for $30 \mathrm{sec}$., annealing at $58^{\circ} \mathrm{C}$ for $45 \mathrm{sec}$. and extension at $72 \mathrm{oC}$ for $45 \mathrm{sec}$. No. of cycles (35) and the final extension was carried out at $72 \mathrm{oC}$ for $10 \mathrm{~min}$.

Table (1):- Designing of Shiga toxin genes primers for E. coli

\begin{tabular}{|c|c|c|c|c|}
\hline Target gene & & Sequence & Amplified product & Reference \\
\hline \multirow[t]{2}{*}{ Stx 1} & $F$ & ACACTGGATGATCTCAGTGG & $614 \mathrm{bp}$ & \multirow{4}{*}{$\begin{array}{l}\text { Dipineto } \\
\text { al., } 2006\end{array}$} \\
\hline & $R$ & CTGAATCCCCCTCCATTATG & & \\
\hline \multirow[t]{2}{*}{ Stx 2} & $F$ & CCATGACAACGGACAGCAGTT & \multirow[t]{2}{*}{779 bp } & \\
\hline & $\bar{R}$ & CCTGTCAACTGAGCAGCACTTTG & & \\
\hline
\end{tabular}

DNA Sequencing for Stx 2 gene isolated from mastitic cattle and contact human:-

A purified RT-PCR product was sequenced in the forward and/ or reverse directions on an Applied Biosystems 3130 automated DNA Sequencer (ABI, 3130, USA). Using a ready reaction Bigdye Terminator V3.1 cycle sequencing kit. (Perkin-Elmer/Applied Biosystems, Foster City, CA), with Cat. No. 4336817. A BLAST® analysis (Basic Local Alignment Search Tool) (Altschul et al., 1990) was initially performed to establish sequence identity to GenBank accessions.

\section{Phylogenetic analysis:-}

A comparative analysis of sequences was performed using the CLUSTAL W multiple sequence alignment program, version 1.83 of MegAlign module of Laser gene DNAStar software Pairwise, which was designed by (Thompson et al., 1994) and Phylogenetic analyses were done using maximum likelihood, neighbour joining and maximum parsimony in MEGA6 (Tamura et al., 2013).

\section{Results:-}

Incidince of $E$. coli isolates on the examined samples:

A total of $11 E$. coli isolates were isolated from the examined samples. From clinical mastitic milk samples E. coli were 5 isolates $(10 \%)$, from sub clinical mastitic milk samples 3 isolates $(7.4 \%)$, while from contact human hand swabs $E$. coli were 3 isolates with percentage of $(7.5 \%)$. E. coli isolates were serotyped under 6 different $\mathrm{O}$ serotypes (O 27, O 55, O6, O86, O114 and O 157 ) . O 27, O 157, O86, O114 from mastitic milk samples and O 27 and $\mathrm{O} 55$ from contact human hand swabs.

\section{Antibiotic sensitivity determination}

All E. coli isolates were fully susceptible to enerofloxacin (100\%), followed by ciprofloxacin (90\%) and sulpha /trimethoprim and gentamicin (70\%). While moderate sensitivity to oxytetracyclin (40\%). On the other hand all isolates were fully resistant to penicillin and amoxicillin/Clavulanicacid.

\subsection{Detection of Shiga toxin genes in $E$. coli serogroupes}

E. coli serogrouped isolates were examined for detection of Shiga toxin virulence genes by duplex PCR. stx2 gene was detected in STEC isolates ( O27, O55) from contact human and in O86 from mastitic milk while stx1 gene was not detected at all as shown in figure (1) and (2).

Results of sequencing of Sxt2 gene of E. coli isolated from cattle mastitis and contact human hand swabs: Figure ( 3 ) demonstrated the identity and the diversion percent against the selected sequences, it revealed that Sxt2 gene (MG656983) isolated from mastitic milk of cattle (sample 1) was closely identical (100\% identity) to Sxt2 gene (MG656984) isolated from contact human (sample 2). However they were showed identity percentage of (99.7\%) with E. coli strain SWUN4041 Stx2 (KP120720.1), E. coli strain SWUN4110 Stx2 (KP120725.1), E. coli 
strain SWUN4061 Stx2 (KP120721.1) and E. coli strain SWUN4035 Stx2 (KP120719.1) which were isolated from Yak animal. Also the percentage of identity reached (99.6\%) with E. coli strain G5101 Sxt 2 (EF441604.1) associated with disease outbreaks in human and E. coli strain RM10058 Stx2 (KF932368.1) which isolated from brown headed cow bird. The phylogenetic tree from the nucleotide sequences (Figure 4 ) and the amino acid sequences (Figure 5)

which represent hypotheses about the evolutionary relationships among a group of sequences . In which the length of the horizontal line connecting one sequence to another was proportional to the estimated genetic distance between the sequences. The phylogenetic analysis in this study revealed that $S x t 2$ gene (MG656983) isolated from mastitic milk of cattle (sample 1) and Sxt2 gene (MG656984) isolated from contact human (sample 2) were found in the same very short branch as they were closely related to each other and that indicate identical sequences. On the other hand they were highly related to Sxt2 gene of Yak origin (KP120720.1), (KP120725.1), (KP120721.1) and (KP120719.1) and Sxt2 gene of human origin (EF441604.1), (KF932368.1) .

\section{Discussion:-}

The incidence of $E$. coli mastitis in the present study was $(10 \%)$ in clinical mastitis and (7.4\%) in subclinical mastitis. Our findings are in accordance with the finding of Baloch et al., 2011 ; Chen et al., 2012 ; Sylejmani et al., 2015 and Mekonnin et al., 2016) who isolated E. coli with percentage of $(10.0 \%),(12.4 \%),(13.4 \%)$ and (14.29\%) respectively. Higher incidence of $E$. coli mastitis was reported by (Nadeem et al., 2013) with percentage of (37.50\%), (Rafik et al., 2014) with (25.5\%) and (Chandrasekaran et al., 2014) with percet of (40.4\%). Lower incidence was recorded by (Cervinkova et al., 2013) with (6.6\%) and (Abera et al., 2013) with (5.71\%). Incidence of E. coli mastitis is quite high . it could be due to poor hygienic conditions as it is environmental pathogen and infect the udder through the teat canal. In this study there was no predominant serogroup among the serotyped strains of $E$. coli and this agree with (Linton et al., 1984 ; Valenete et al., 1988) also agree with (Amira et al., 2013) in Egypt, and this emphasized that serotyping of $E$. coli not of high significance in mastitis cases characterization. This observation had been reported by (Bradley et al., 2000 ; El-Mahronki et al., 2006). E. coli isolates detected in this study were serotyped to different serogroups as O27, O55, O157, O86, O114 and O6.

$\mathrm{O} 86$ and $\mathrm{O} 114$ are enteropathogenic E. coli (EPEC) strains and were also isolated from lactating cow milk by (Abdallah et al., 2014 ; Abdel kerim et al., 2015 ). While (Salwa et al., 2011) detected O114 and O157 E. coli serogroups from mastitic cases. Another study (Osman et al., 2012) reported that, E. coli isolates from mastitic milk samples, belonged to four different O serogroups (O26, O86, O111, and O127). O157 was among the serotyped E. coli strains recovered from mastitis cases and this serogroup is considered as enterohemorrhagic E. coli (EHEC) is the predominant and most virulent serotype in a pathogenic subset of STEC ( OIE, 2004). Cattle are considered the main reservoir of this serotype. O157 is one of the most important STEC that causes severe disease in human and was reported by many other authors as a cause of mastitis (Lipman et al., 1995 ; Aly, 2006 ). In the present study E. coli was isolated from contact human hand swabs with percentage (7.5\%). It was isolated from dairy workers in Egypt with percentages (11.1\%) by (Awadallah et al., 2016 ), 16\% by (Zeinhom and Abdel-Latef , 2014) and $20 \%$ by (Gwida and El-Gohary, 2013 ).

Isolation of $E$. coli from the hand of contact human and dairy workers may be attributed to poor hygienic measures during milking and poor personal hygiene practices in dairy workers. These results indicate the possibility of transferring $E$. coli to milk and consequently increasing the risk of infection for milk consumers (El-Gedawy et al., 2014). Regarding to E. coli isolated from contact human serotypes O27 and O55 were isolated. Strain O55 is considered as enteropathogenic E. coli (EPEC) strain and was isolated from contact workers in Egypt by (Merwad et al., 2014). Also O55 and O27 were isolated from dairy cows, and hand swabs of dairy workers by (Awadallah et al., 2016). Severe gastrointestinal diseases in humans and complications such as the haemolytic uremic syndrome can caused by Shiga toxin-producing E. coli (STEC) and it is considered as an important group of food-borne pathogens. Chern et al. (2004) and Kobori et al., (2004). Also several authors recorded that Shiga toxins genes (Stx1, Stx2) and ea (intimin) gene are the most important virulence genes in E. coli strains isolated from bovine mastitic milk Kobori et al. (2004), Wieler et al. (1996) and Paton et al. (1998). So that in the current study multiplex PCR protocol used for detection of stx 1 and stx 2 genes on isolated E. coli serogroups to confirm their pathogenicity. stx 2 gene was detected in STEC isolates from contact human and mastitic milk. While stx1gene was not detected. Similar results was mentioned by (Singha et al., 2013) who reported that only one isolate was positive for shiga toxin gene (stx2), and none were harbouring stx1 gene from dairy cattle suffering from clinical/subclinical mastitis. While 
Merwad et al., 2014) detected the presence of st 1 , st 2 , both st 1 and st $x 2$ in E. coli isolated from contact workers and milk. On the other hand ,( Murinda et al., 2004 ; Carneiro et al., 2006 ; Wenz et al., 2006) mentioned that E. coli strains isolated from cows with mastitis are negative for stx2 gene by PCR. (Osman et al., 2012) found that STEC isolates were not found in bovine mastitic milk in Egypt. While (Farhad et al., 2012 ; Bean et al., 2004) showed that the most common virulence gene detected in mastitic milk samples was stx 1 . In the present study the phylogenetic analysis revealed that $S x t 2$ gene (MG656983) isolated from mastitic milk of cows (sample 1) and Sxt2 gene (MG656984) isolated from contact human (sample 2) were found in the same very short branch as they were closely related to each other and that indicate identical sequences. On the other hand they were highly related to $S x t 2$ gene of Yak origin (KP120720.1), (KP120725.1), (KP120721.1) and (KP120719.1) and Sxt2 gene of human origin (EF441604.1), (KF932368.1). This result agreed with (Asakura et al., 2000) who recorded that Stx of STEC isolated from cattle, seagulls and flies were closely related to those of human-origin STEC. (Murinda et al., 2004) investigated that E.coli isolates from cattle and human disease shared similar toxigenic profiles. These findings suggesting that the toxin of STEC from cows might have potential pathogenicity for human. So that contact human should use sound hygienic measures during milking and management of these animals to avoid zoonoticinfection

\section{Conclusion:-}

Detection and treatment of $E$. coli mastitis appear to be important for animal health and has a public health for contact human. No association between strain serotype and the presence of shiga toxin genes and clinical disease severity. Enerofloxacin and ciprofloxacin were the most effective antibiotics on treatment of E. coli mastitis. phylogenetic analysis revealed that $S x t 2$ gene isolated from mastitic cattle is closely identical (100\% identity) to Sxt 2 gene isolated from contact human. These findings suggesting that the toxin of STEC from cattle might have potential pathogenicity for human. So that contact human should use sound hygienic measures during milking and management of these animals to avoid zoonotic infection.

Figure (1): Gel electrophoresis pattern for detection of Shiga toxin genes in E. coli serogroups: Lane 2: amplification of (Stx2) gene at 779 bp in sample 2 (O55) from contact human hand swabs. L: ladder. Pos: positive control (Stx 1 at 614 bp, Stx 2 at 779 bp ). N: Negative control.

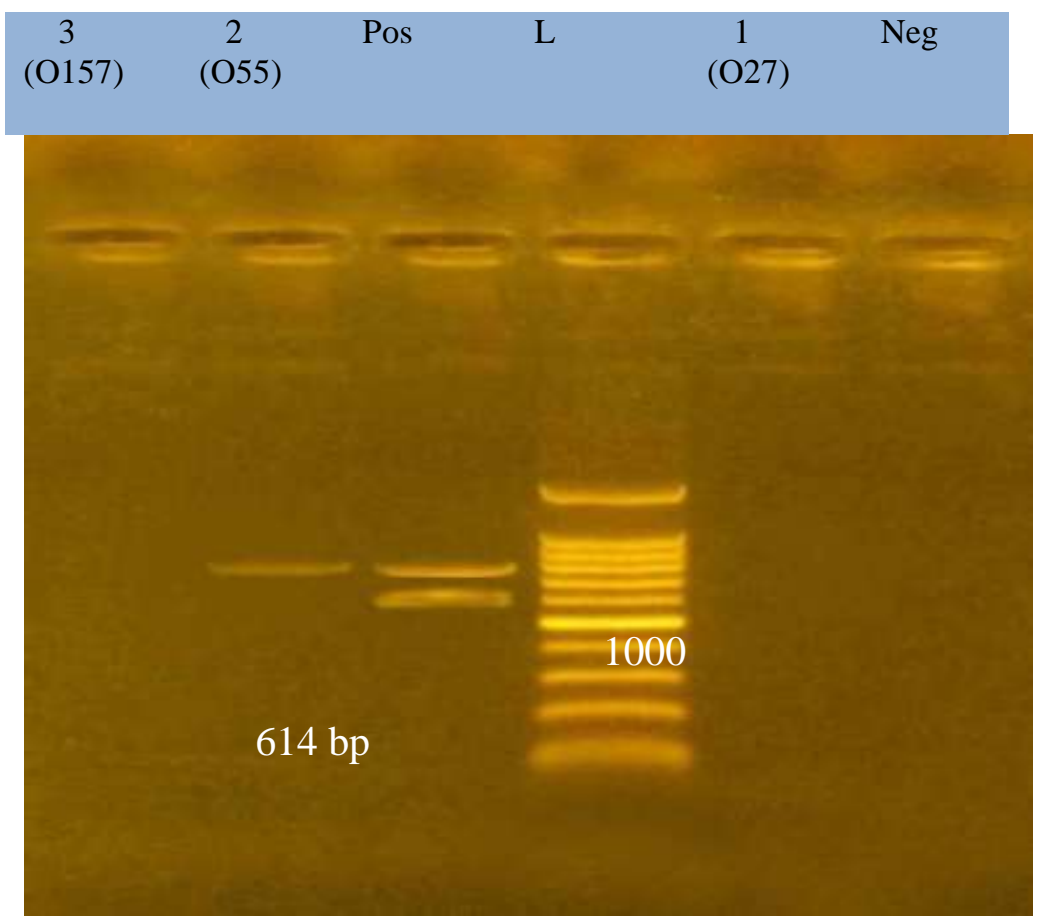

Figure (2):- Gel electrophoresis pattern for detection of Shiga toxin genes in E. coli serogroups: Lane 5, 7 :positive amplification of (Stx2) gene at 779 bp in serogroupe (O86) and (O27) from contact human hand swabs . L: ladder. 
Pos: positive control (Stxl at $614 \mathrm{bp}$, Stx 2 at $779 \mathrm{bp})$. N: Negative control

$\begin{array}{lllllll}7 & 6 & 5 & 4 & \text { Neg } & \text { Pos } & \text { L } \\ (\mathrm{O} 27) & (\mathrm{O} 114) & (\mathrm{O} 86) & (\mathrm{O} 6) & & & \end{array}$

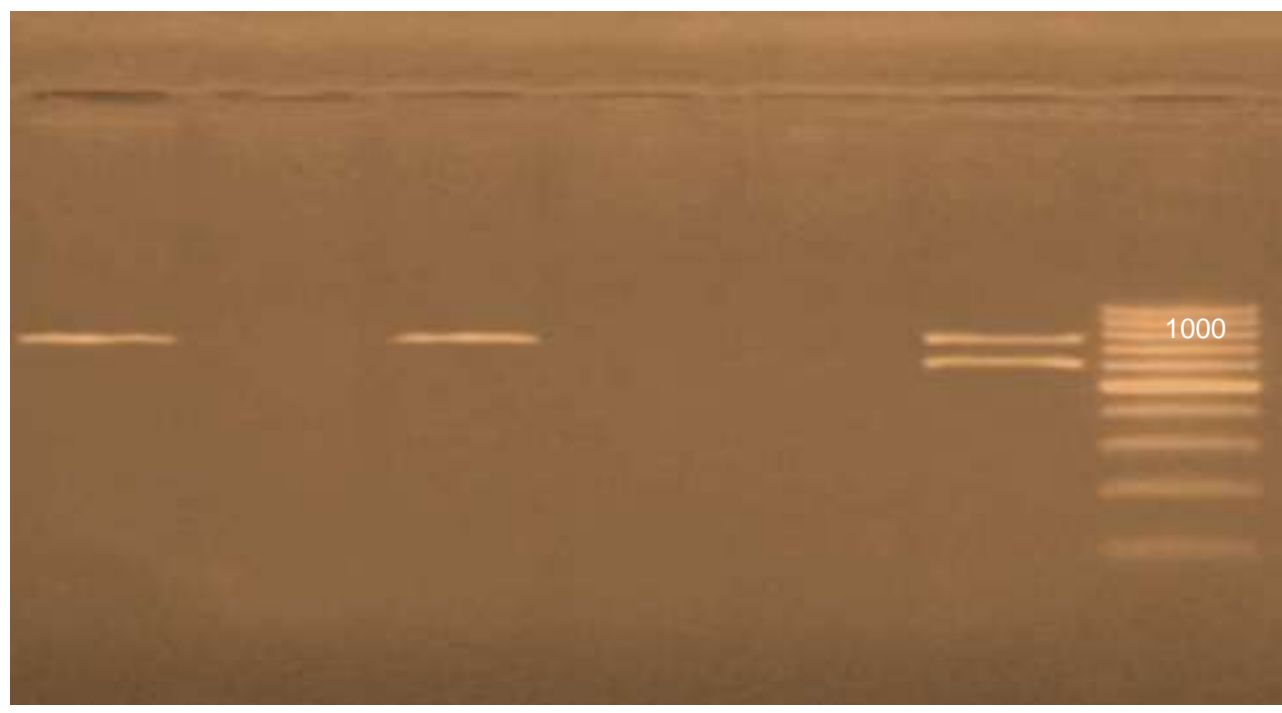

Figure (3):- Identity and diversion percent of amino acid sequence of sample 1 (Sxt2 gene of E. coli MG656983) mastitic milk of cattle and sample 2 (Sxt2 gene of E. coli MG656984) isolated from contact human hand swabs with 30 of the most similar Sxt2 gene amino acid sequences from Gene bank.

Pacert bentty

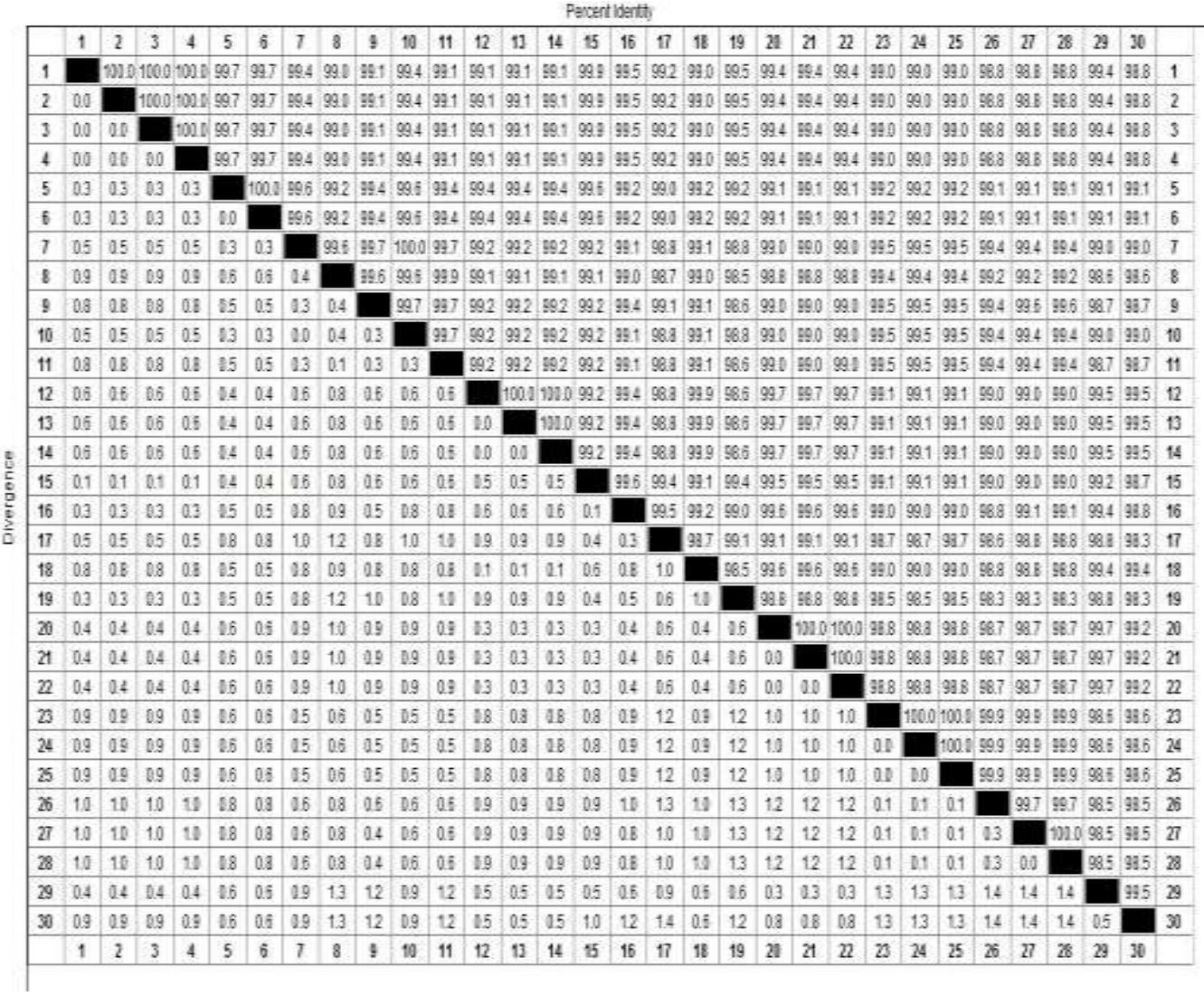

KPQI72. KP t2uา: KP 2u721. KP 21715.1 Sanple 1 Sample 2 EF416041 169432.1 EUT52734.1 KF952358.1 EF410031 AF5us193. AFAmere.1 G0eg15:. KPา28717.1 Ger29157. AY443:45: HP43:47: . 02064451 Algs3:48.1 Goes172.1 EUT54722.1 L11ม7:. KF9S23021 Fump 471.1 FR351145:1 Hแ3829212 KF952363.1 Al 3938501 Algg3:40.1 
Figure (4):- phylogenic tree for amino acids sequence of sample 1 ( $S x t 2$ gene of E. coli MG656983) isolated from mastitic milk of cattle and sample 2 (Sxt2 gene of E. coli MG656984) isolated from contact human hand swabs with 30 of the most similar $S x t 2$ gene amino acid sequences from Gene bank.

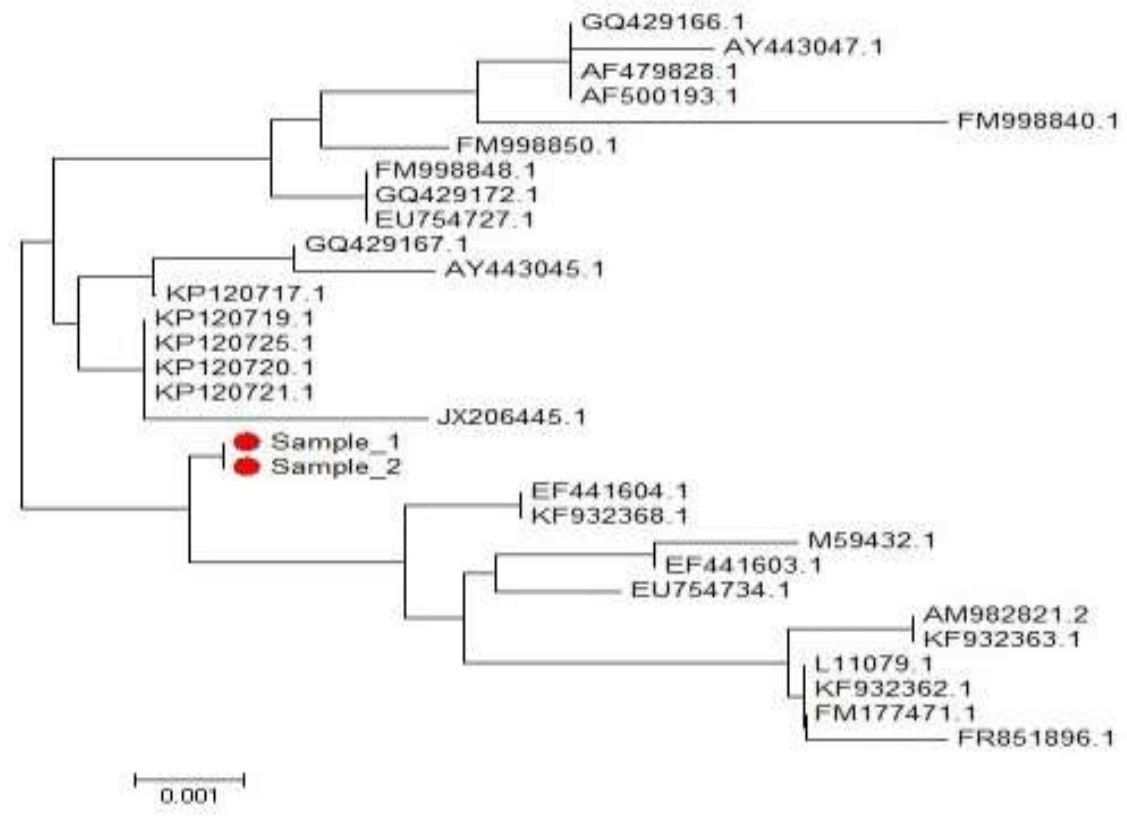

Figure (5):- phylogenic tree for nucleotide sequence of sample 1 (Sxt2 gene of E. coli MG656983) isolated from mastitic milk of cattle and sample 2 ( $S x t 2$ gene of $E$. coli MG656984) isolated from contact human hand swabs with 30 of the most similar $S x t 2$ gene amino acid sequences from Gene bank.

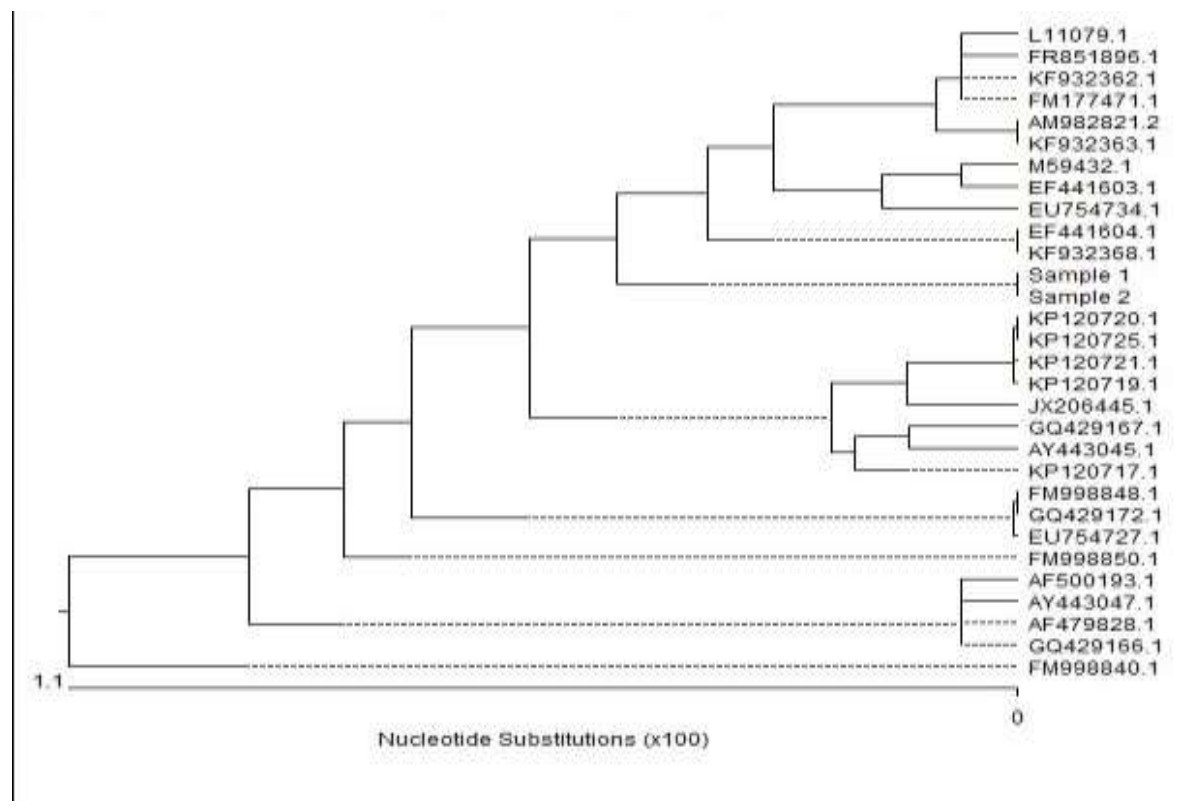




\section{Refrances:-}

1. Abdel kerim AM, Adel MK, Tharwat M E, Hassan AH and Mohamed II. Some Studies on E-Coli Mastitis in Cattle and Buffaloes. Alexandria Journal of Veterinary Sciences, 2015; 45: 105-112.

2. Abdallah M, Rasha G. and Taisir, S. Occurrence of shiga toxin-producing Escherichia coli in lactating cows and in contact workers in Egypt: serotypes, virulence genes and zoonotic significance.Life Science Journal , 2014; 11(5).

3. Abera B, Lemma D, and Iticha L. Study of bovine mastitis in asella government dairy farm of Oromia Regional state, South Eastern Ethiopia : Int.J. Curr. Res. Aca. Rev. 2013; 1(2) 134-145.

4. Addis M, Pal M. and Kyule MN. Isolation and identification of Staphylococcus species from raw bovine milk in Debre Zeit, Ethiopia. Veterinary Research, 2011a; 4 (2): 45-49.

5. Altschul SF, Gish W, Miller W, Myers EW. and Lipmanl DJ. Basic Local Alignment Search Tool. J. Mol. Biol; $1990 ; 215,403-410$.

6. Aly, R.G.O., (2006): Coliform mastitis in farm animals. M.V.Sc. thesis (Microbiology), Fac. Vet. Med. Cairo Univ.

7. Amira E.L, Ammar A.M. and Zaki E.R. (2013): Virulence factors of Echerichia coli isolated from recurrent cases of clinical and subclinical mastitis in buffaloes, International Journal of Microbiologicale Research ;4(1): $86-94$.

8. Asakura H, Makino S, Kobori H, Watarai M, Shirahata T, Ikeda T. and Takeshi K. Phylogenetic diversity and similarity of active sites of Shiga toxin (stx) in Shiga toxin-producing Escherichia coli (STEC) isolates from humans and animals. Epidemiol Infect, 2000; 127(1):27-36.

9. Awadallah MA, Ahmed HA, Merwad AM. and Selim MA. Occurrence, genotyping, shiga toxin genes and associated risk factors of $E$. coli isolated from dairy farms, handlers and milk consumers. Vet. J., 2016; (217):83-88.

10. Baloch H, Rind R, Kalhoro DH. and Kalhoro AB. Study on the incidence of clinical mastitis in buffaloes caused by bacterial species . Pac.J.Agri., Agril,Engg,Vet.Sci. 2011;27(1):83-93.

11. Bean A, Williamson J, Cursons RT. Virulence genes of Escherichia coli strains isolated from mastitic milk. Journal of Veterinary Medicine Series B. 2004; 51(6):285-287.

12. Bradley AJ. and Green MJ. A study of the incidence and significance of intramammary enterobacterial infections acquired during the dry period. Journal of Dairy Science, 2000; 83(9): 1957-1965.

13. Blanco J E, Blanco M, Alonso MP, Mora A, Dahbi G, Coira MA. and Blanco J. Serotypes, virulence genes, and intimin types of shiga toxin (verotoxin)-producing Escherichia coli isolates from human patients: prevalence in Lugo, Spain, from1992 through 1999. Journal of Clinical Microbiology,2004a; 42(1): 311-319.

14. Carneiro LA, Lins MC, Garcia FR, Silva AP, Mauller PM, Alves GB , Rosa AC , Andrade JR, FreitasAlmeida AC. and Queiroz ML. Phenotypic and genotypic characterization of Escherichia coli strains serogrouped as Enteropathogenic E. coli (EPEC) isolated from pasteurized milk. International Journal of Food Microbiology; 2006; 108(1): 15-21.

15. Cervinkova D, Vilkova H, Macovocova J, Babak V, Lorencova A, Vrtkova I, Marosevic, D, and Taglic , Z. Prevalence of Mastitis pathogens in milk from clinically healthy cows., Vetrinarini Medicina, 2013;58(11):567575.

16. Chandrasekaran D, Rankatesan P, Tirumurugaan KG, Nambi AP, Thirunavukkarasu PS, Kumanan K, Vairamuthu S. and Ramesh S. Pattern of antibiotic resistant mastitis in dairy cows. Vetirinary World, 2014; 7(6): 389-394.

17. Chen YY, Yang ZT, Liu WB, Chang QC, Wang LG. and Zhang NS. Prevalence and Major Pathogen Causes of Dairy Cows Subclinical Mastitis in Northeast China. Journal of Animal and Veterinary Advances, 2012; 11(8): 1278-1280.

18. Chern EC, Tsai YL. And Olson BH. Occurrence of genes associated with ente- rotoxigenic and enterohemorrhagic Esche-richia coli in agricultural waste lagoons. Applied Environmental Microbiology 2004; 70: 356-362.

19. Dipineto L, Santaniello A, Fontanella M, Lagos K, Fioretti A. and Menna LF. Presence of Shiga toxinproducing Escherichia coli O157:H7 in living layer hens. Letters in Applied Microbiology $2006 ; 43$ :293-295.

20. El-Gedawy AA, Ahmed HA. and Awadallah MAI. Occurrence and molecular characterization of some zoonotic bacteria in bovine milk, milking equipments and humans in dairy farms, Sharkia, Egypt. International Food Research Journal 2014 ; 21(5): 1813-1823.

21. El-Mahronki AM, Sobhy NM. and Aggour MG. Detection of coliform mastitis in cattle with special reference to molecular characterization of enterotoxigenic E. coli using polymerase chain reaction (PCR). J. Egypt Vet. Med. Assoc. 2006; 66: 47-58. 
22. Fekadu, K. (1995): survey on the prevalence of bovine mastitis and the predominant causative agents in chaffa valley. Proceedings of the 9th conference of Ethiopian veterinary Association: Addis Ababa, Ethiopia.pp.101 111.

23. Farhad SD, Taghi T, Amir R. and Sajad HMY. Shiga Toxin-Producing Escherichia coli Isolated from Bovine Mastitic Milk: Serogroups, Virulence Factors, and Antibiotic Resistance Properties. Scientific World Journal. 2012.

24. Green MJ, Green LE, Bradley AJ, Burton PR, Schukken YH. and Medley GF. Prevalence and associations between bacterial isolates from dry mammary glands of dairy cows. The Veterinary Record 2005; 156, 71-77.

25. Gwida MM, El-Gohary FA. Zoonotic bacterial pathogens isolated from raw milk with special reference to Escherichia coli and Staphylococcus aureus in Dakahlia Governorate, Egypt. Open Access Scientific Reports 2013; 2, 705.

26. Kaipainen T, Pohjanvitra T, Sphigel NY, Shwimmer A, Pyolara S. and S. Pelkonen. Virulence factors of E. coli isolated from bovine clinical mastitis. Veterinary Microbiology 2002; 85 (1): 37-46.

27. Keen JE, Wittum TE, Dunn JR, Bono JL. and Durso LM. Shiga-toxigenic Escherichia coli O157 in agricultural fair livestock, United States. Emerging Infectious Diseases 2006; 12(5):780-786.

28. Kobori DE, Rigobelo C, Macedo C, Marin JM. and Avila FA. Virulence properties of shiga toxin-producing Escherichia coli isolated from cases of bovine mastitis in Brazil. Révue d'Elevage et de Médecine Vétérinaire des Pays Tropicaux 2004; 57: 15-20.

29. Linton AH. and Robinson TC. Studies on the association of Escherichia coli with bovine mastitis. British Veterinary Journal 1984; 140: 368-373.

30. Lipman LJ, De Nijs A, Lam TJ. and Gaastra W. Identification of Escherichia coli strains from cows with clinical mastitis by serotyping and DNA polymorphism patterns with REP and ERIC primers. Veterinary Microbiology 1995; 43(1): 13-19.

31. Merwad A, Gharieb R. and Saber T. Occurrence of shiga toxin-producing Escherichia coli in lactating cows and in contact workers in Egypt: serotypes, virulence genes and zoonotic significance. Life Science Journal $2014 ; 11(5)$.

32. Mekonnen H, Workineh S, Bayleyegne M, Moges A. and Tadele K. Antimicrobial susceptibility profile of mastitis isolates from the cows in three major Ethiopian dairies. Med. Vet 2005; 176(7): 391394

33. Mekonnin E, Eshetu E, Awekew A. and Thomas NA. Study on the Prevalence of Bovine Mastitis and Associated Risk Factors in and the Surrounding areas of Sodo Town,Wolaita Zone, Ethiopia. Global Journals Inc. (USA) 2016; 16(2).

34. Momtaz H, Froutan MS, Taktaz T. and Sadeghi M. Molecular detection of Streptococcus uberis and Streptococcus agalactiae in the mastitic cow's milks in Isfahan province. Biological Journal for Microorganism 2012; 2(1).

35. Murinda SE, Nguyen LT, Landers TL, Draughon FA, Mathew AG, Hogan JS, Smith KL, Hancock DD. and Oliver SP. Comparison of Escherichia coli Isolates from humans, food, and farm and companion animals for presence of Shiga toxin-producing E. coli virulence markers. Foodborne Pathogwn Dis 2004; 1(3):178-84.

36. Nadeem A, Chaudhary HA, Ahmed GMA, Nawaze G. and Hussain S. Isolation of bacteria from mastitis affected bovine milk and their antibiogram, European Journal of Veterinary Medicine 2013; 2(1) :38-46.

37. Nemeth J, Muckle CA. and Gyles CL. In vitro comparison of bovine mastitis and fecal Escherichia coli isolates. Vet. Microbiol 1994; 40:231-238.

38. NMC. Current Concept in bovine mastitis National mastitis Council (NMC). 3rd .1840 Wilson blud, Arlinton, 1999; VA 22201.

39. OIE. (2004) : Verocytotoxigenic Escherichia coli . In: Manual of Diagnostic Test and Vaccines for Terrestrial Animals. World Organisation for Animal Health (OIE) ; Available: http://www.oie.int.

40. Ojo OE, Ajuwape ATP, Otesile E B, Owoade AA, OIyekunle M A. and Adetosoye A I. Potentially zoonotic shiga toxin-producing Escherichia coli serogroups in the faeces and meat of food producing animals in Ibadan, Nigeria. International Journal of Food Microbiology 2010 ; 142 (1-2): 214-221.

41. Osman KM, Mustafa AM, Aly MAK, AbdElhamed GS. Serotypes, virulence genes, and intimin types of Shiga toxin-producing Escherichia coli and enteropathogenic Escherichia coli isolated from mastitic milk relevant to human health in Egypt. Vector-Borne and Zoonotic Diseases 2012; 12(4):297-305.

42. Paton JC. and Paton AW. Pathogenesis and diagnosis of Shiga toxin-producing Escherichia coli infections. Clinical Microbiology Reviews 1998; 11(3):450-479.

43. Quinn PJ, Carter ME, Markey BK. and Carter GR. Clinical Veterinary microbiology. Harcourt publishers, Virginia, pp.2002; 331-344. 
44. Radostits OM, Gay CC, Blood DC. and Hinchcliff KW. Mastitis In :Veterinary medicine 9thed.,Harcourt Ltd, London 2007; 174-758.

45. Rafik HS, Selim SS. and Rafik TS. Bacteriological Evaluation of Present Situation of Mastitis in Dairy Cows, Global Veterinaria 2014; 13 (5): 690-695.

46. Salwa MH, Ammar M A, Aisha RA, Mona AE, Hakim AS. and Bakry M. Molecular and Virulence Characterization of Escherichia. Coli strains Isolated from Persistent Bovine Mastitis: J. Am. Sci. 2011; 7(1).

47. Sambrook J, Fritscgh EF. and Mentiates . Molecular coloning. A laboratory manual. Vol !., Cold spring Harbor Laboratotry press, New York. 1989.

48. Singha A, Sen A, Guha C, Ahuja G SA, Bhattacharjee U, Das S, Pradhan NR, Puro K, Jana C, Dey TK, Prashantkumar KL, Das A, Shakuntala I, Biswas U. and Jana PS. Detection of New Delhi metallo-betalactamase and extended-spectrum beta-lactamase genes in Escherichia coli isolated from mastitic milk samples. Transbound Emerg Dis. 2013; 60(5):385-9.

49. Solomakos N, Govaris A, Angelidis AS. et al. Occurrence, virulence genes and antibiotic resistance of Escherichia coli $\mathrm{O} 157$ isolated from raw bovine, caprine and ovine milk in Greece. Food Microbiology 2009; 26(8):865-871.

50. Sylejmani D, Ramadani N, Robaj A. and Hamidi A. Prevalence and antimicrobial susceptibility of bacterial isolates from sub clinical mastitis in dairy farms in Kosovo .Bulgarian J. of vet Med. 2015; 1311-1477.

51. Tamura K, Stecher G, Peterson D, Filipski A. and Kumar S. MEGA6: molecular evolutionary genetics analysis version 6.0. Mol. Biol. Evol 2013; 30:2725-2729.

52. Tavakoli M. and Pourtaghi H. Molecular detection of virulence genes and multi-drug resistance patterns in Escherichia coli (STEC) in clinical bovine mastitis: Alborz province, Iran. Iranian Journal of Veterinary Research, Shiraz University 2017; 18( 3): 208-211.

53. Thompson JD, Higgins DG. and Gibson TJ. Nucleic Acids Research; 22(22):4673-4680.

54. Thirapatsakun T. Mastitis management. In: small holder dairying in the tropics. In: Hunt and Chantalakhana (Eds). ILRI, Kenya, Nairobi, pp. 1999; 299-339.

55. Valenete C, Cardaras P, Ciorba A. and Tesei B. Studies on virulence factors of Escherichia coli isolated from cows with acute mastitis. Arch. Veter. Italiano 1988; 39: 254-260.

56. Varnam AH. and Evans MG. Salmonella. In: Foodborne pathogens. An illustrated text. Eds: Wolfe Publishing Ltd, Aylesbury, England. 1991.

57. Wenz JR, Barrington GM, Garry FB, Elli RPS. and Magnuson RJ. E. coli isolates`serotypes, genotypes and virulence genes and clinical coliform mastitis severity. Journal of Dairy Science 2006; 89(9): 3408-3412.

58. Wieler LH, Vieler E, Erpenstein C. et al. Shiga toxin-producing Escherichia coli strains from bovines: association of adhesion with carriage of eae and other genes. Journal of Clinical Microbiology 1996); 34(12):2980-2984.

59. Winn W, Allen S, Janda W, Koneman E, Procop G, Schreckenberger P. and Woods G. Koneman'a color Atlas and Textbook of Diagnostic Microbiology. 6th Ed., Lippincott William of Wilkins: London and New York. 2006.

60. Zeinhom MMA. and Abdel-Latef GK. Public health risk of some milk borne pathogens. Beni-Suef University Journal of Basic and Applied Sciences 2014; 3, 209-215. 